\title{
Paleoweathering conditions of Upper Carboniferous siliciclastic rocks of SW Hungary
}

\author{
Andrea Varga \\ D epartment of Petrology and Geochemistry, \\ Eötvös Loránd U niversity, Budapest
}

\section{Zsuzsanna Hartyáni}

D epartment of Earth and Environmental Sciences, U niversity of Pannonia, Veszprém

\section{Béla Raucsik}

D epartment of Earth and Environmental Sciences, U niversity of Pannonia, Veszprém

\author{
György Szakmány \\ D epartment of Petrology and Geochemistry, \\ Eötvös Loránd U niversity, Budapest
}

\begin{abstract}
The clay mineralogical and chemical compositions of Upper Carboniferous siliciclastic rocks from the western flank of the Villány Mountains (Téseny Sandstone Formation) have been investigated to determine paleoweathering conditions, as well as to appraise the influence of the post-depositional processes upon source rock signature. The clay-mineral assemblage of the samples consists predominantly of illite \pm muscovite, suggesting a potassium metasomatism in the Téseny clastics. Therefore the use of the Chemical Index of Alteration (CIA), which provides a consistent quantitative framework for examining weathering, leads to erroneous conclusions without correction for $\mathrm{K}$ metasomatism. When considered in $\mathrm{Al}_{2} \mathrm{O}_{3}-\mathrm{CaO} *+\mathrm{Na}_{2} \mathrm{O}-\mathrm{K}_{2} \mathrm{O}(\mathrm{A}-\mathrm{CN}-\mathrm{K})$ compositional space, orthogneiss and igneous rock clasts selected from the Téseny conglomerate reflect two different weathering trends; one (including orthogneiss, quartz diorite, and andesite samples) shows an ideal trend observed for granodioritic rocks, and the other (including aplite, rhyodacite, and rhyolite samples) follows a trend from a slightly more K-feldspar-rich fresh rock composition than that of average granite. Intermediate to intense chemical weathering of the source areas is indicated by premetasomatized $\mathrm{ClA}$ values of 77-84 for the samples from borehole Siklósbodony-1, suggesting that these rocks have gained about 6-7\% $\mathrm{K}_{2} \mathrm{O}$ (in A-CN-K space) during metasomatism.
\end{abstract}

Key words: sandstone, conglomerate, clay mineralogy, major elements, continental weathering, potassium metasomatism

Addresses: A. Varga, Gy. Szakmány: H-1117 Budapest, Pázmány Péter sétány 1/C, Hungary, e-mail: raucsikvarga@freemail.hu

B. Raucsik, Zs. Hartyáni: H-8201 Veszprém, P.O. Box 158, Hungary

Received: March 23, 2007, accepted: May 14, 2007 


\section{Introduction}

The search for a better understanding of the main factors controlling the chemical weathering rates of silicate minerals and rocks at the surface of the Earth is a major geologic concern (Nesbitt et al. 1980; Nesbitt and Young 1984, 1989; Gaillardet et al. 1999). There are different ways to characterize both the modern and past weathering conditions and to address the control of weathering rates. Clay mineralogy is widely considered to be a powerful tool for interpreting weathering conditions and pal eoclimate in the source area (Weaver 1989). On the other hand, the effect of variable degrees of subaerial weathering in source areas can be important in influencing alkali and alkaline earth element abundances in siliciclastic sediments (N esbitt et al. 1980; N esbitt and Young 1982; Gaillardet et al. 1999). M olecular proportions of $\mathrm{CaO}, \mathrm{Na}_{2} \mathrm{O}, \mathrm{K}_{2} \mathrm{O}$, and $\mathrm{Al}_{2} \mathrm{O}_{3}$ from modern clastic silicate detritus reflect the degree of chemical weathering in their source; thus, the elemental compositions of ancient siliciclastic rocks may be used in a similar way to make inferences about past weathering conditions (Nesbitt and Young 1984, 1989).

A common approach to quantify the degree of continental weathering is to use the Chemical Index of Alteration (CIA) (Nesbitt and Young 1982). The CIA is calculated by the following formula: $\mathrm{ClA}=\left[\mathrm{Al}_{2} \mathrm{O}_{3} /\left(\mathrm{Al}_{2} \mathrm{O}_{3}+\mathrm{CaO} *+\mathrm{Na}_{2} \mathrm{O}+\mathrm{K}_{2} \mathrm{O}\right)\right]$ $\times 100$ (molar proportions). $\mathrm{CaO} *$ represents $\mathrm{Ca}$ in silicate-bearing minerals only. This index measures the degree of weathering of feldspars, relative to unweathered protoliths (e.g. igneous rocks). Plagioclase, K-feldspar, other alkaliand alkaline earth Al-silicates and volcanic glass weather to clay minerals, the feldspars commonly to kaolinite and illite, the mafic minerals and glass commonly to smectites as well as to kaolinite and illite (N esbitt et al. 1980; Nesbitt and Young 1984, 1989; Weaver 1989). CIA values for unweathered plagioclase and K-feldspars are approximately equal to 50, as are values of unweathered upper crustal rocks. The CIA value of illite and kaolinite are 75 and 100, respectively. $\mathrm{Higher} \mathrm{CIA}$ values represent higher degrees of source area weathering (Nesbitt et al. 1980; Nesbitt and Young 1982, 1984, 1989).

Thermodynamic principles and kinetic data allow a prediction of the paths followed by rainwater-derived solutions during reactions with crustal rocks (Nesbitt and Young 1984). The $\mathrm{Al}_{2} \mathrm{O}_{3}-\mathrm{CaO} *+\mathrm{Na}_{2} \mathrm{O}-\mathrm{K}_{2} \mathrm{O}(\mathrm{A}-\mathrm{CN}-\mathrm{K})$ system is useful for evaluating fresh rock compositions and examining their weathering trends because the upper crust is dominated by plagioclase and K-feldspar-rich rocks and their weathering products, the clay minerals (Nesbitt and Young 1984, 1989). Thermodynamic and mass balance considerations suggest that the results of the weathering of both volcanic and plutonic rocks are similar (Nesbitt and Young 1984). The bulk compositions of igneous rocks follow simple trends that are largely unaffected by climatic conditions under which weathering proceeds (Fig. 1). The initial weathering trends are subparallel to the $\left(\mathrm{CaO} *+\mathrm{Na}_{2} \mathrm{O}\right)-\mathrm{Al}_{2} \mathrm{O}_{3}$ boundary, primarily because removal rates of $\mathrm{Na}$ and $\mathrm{Ca}$ from plagioclase or volcanic material (glass) generally are greater than the removal rate of $\mathrm{K}$ from $\mathrm{K}$ - 
Fig. 1

The A-CN-K system (molar proportions) for evaluating fresh rock compositions and examining their subaerial weathering trends (Nesbitt and Young 1984, 1989). Average chemical data for igneous rocks (TTG = tonalite-trondhjemitegranodiorite) represent typical unweathered protoliths (Condie 1993)

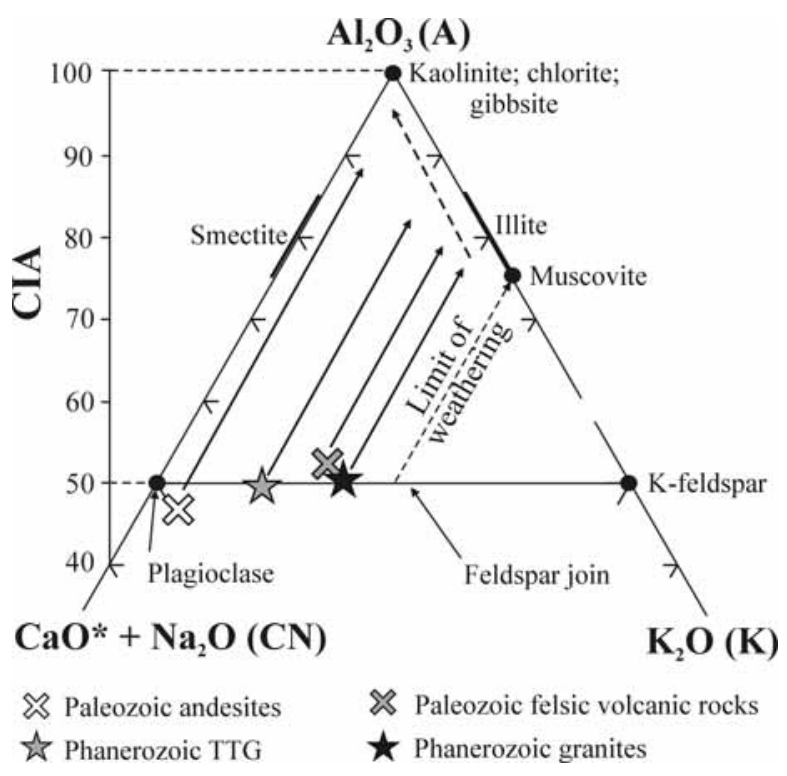

feldspar or glass. With more advanced weathering, compositions trend from illite-muscovite toward the A apex, along the A-K join (N esbitt and Young 1984, 1989). Within the compositional space represented by the $A-C N-K$ diagram, the vertical dimension (percent $\mathrm{Al}_{2} \mathrm{O}_{3}$, molar) corresponds to the values of the $\mathrm{CIA}$ (Nesbitt and Young 1989).

The geochemistry of the Upper Carboniferous continental sedimentary rocks in Hungary and the related information about weathering has not received much attention in the literature. Recently, Varga et al. (2001, 2002, 2003, 2004, 2007) and Varga and Szakmány (2004) reported the mineralogical, petrographic, and chemical composition of these rocks. In this study we include data from clay mineralogical and bulk-rock geochemical analyses of sandstone, sandy siltstone, and conglomerate samples collected from the Upper Carboniferous Téseny Sandstone Formation (Slavonia-Drava Unit, Tisza Mega-unit, Hungary) to describe paleoweathering conditions. Based on the A-CN-K relationship we specifically discuss the degree of chemical weathering and the influence of the post-depositional processes such as K-metasomatism upon rock signature. It is beyond the scope of this manuscript to discuss the provenance and tectonic setting of Téseny rocks. This is addressed in detail in previous separate papers (Varga et al. 2001, 2003, 2004, 2007; Varga and Szakmány 2004). 


\section{A. Varga et al.}

\section{$M$ aterials and methods}

Geologic setting and lithology

At the end of the Variscan cycle the polymetamorphic complexes of the Slavonia-Drava Unit (Tisza Mega-unit, Hungary) belonged to the southern part of the Moldanubian Zone (Variscan Orogenic Belt) forming the European margin of the Paleotethys Gulf (Haas et al. 1999). Variscan post-orogenic sedimentation produced a Late Carboniferous, non-metamorphic (locally anchimetamorphic) molasse-type overstep sequence, which was draped over the eroded surface of the crystalline basement (Hetényi and Ravasz-Baranyai 1976; Fülöp 1994; Szederkényi 2001). The coal-bearing Upper Carboniferous continental succession (Téseny Sandstone Formation), which is interpreted as fluvial system deposits, occurs in subsurface in southern Transdanubia on the western flank of the Villány Mountains and west of it (Fig. 2). This formation is composed of conglomerate, sandstone, and siltstone; in addition, shale and coal seams also occur (Jámbor 1969; Hetényi and Ravasz-Baranyai 1976; Varga et al. 2003). These rocks contain a Namurian-Westphalian flora composed of the Pecopteris, Sphenopteris, N europteris, Alethopteris, Sphenophyllum, Annularia, Calamites assemblage and Westphalian palynomorphs (Hetényi and Ravasz-Baranyai 1976).

Petrographically, the Téseny sandstone and sandy siltstone samples are composed of variable amounts of quartz grains, feldspar, mica, chlorite, clay, Fe

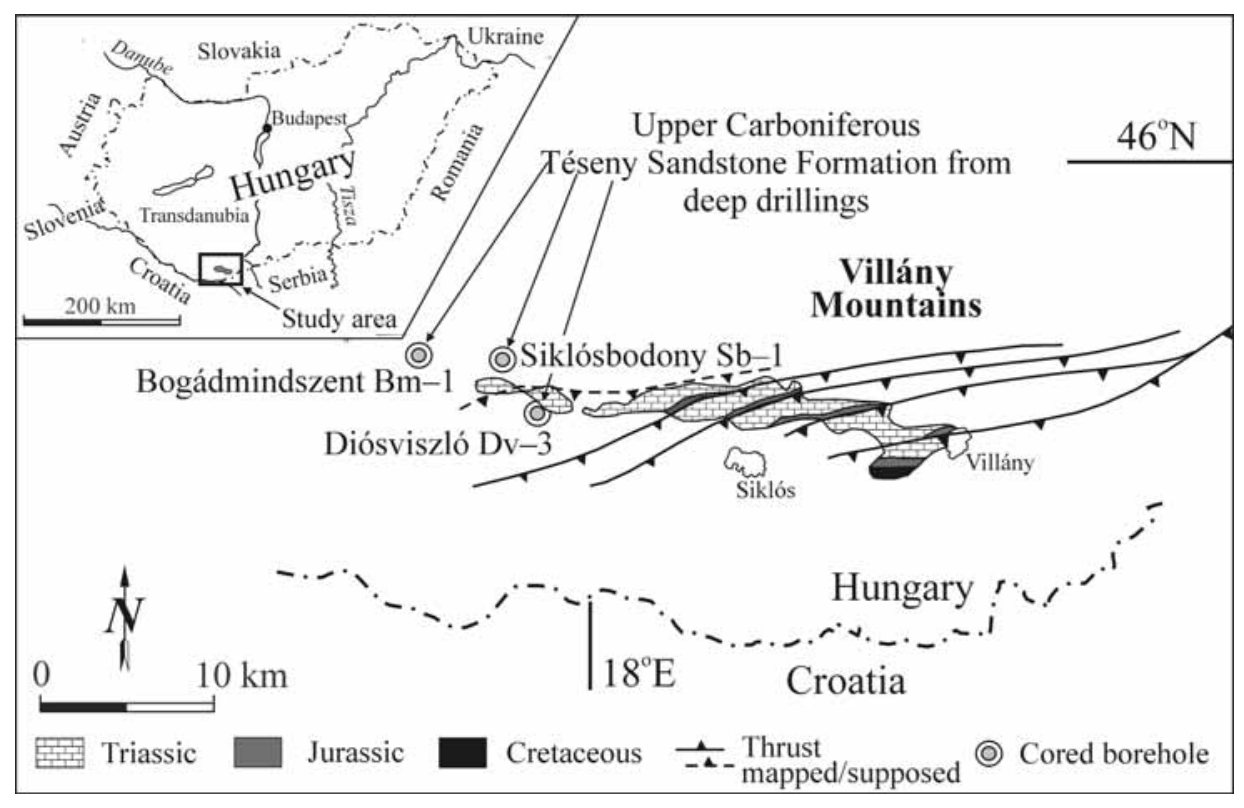

Fig. 2

Simplified geologic map of the Villány area (southern Transdanubia, Hungary) showing the localities where samples were collected for this study (after Varga et al. 2007) 
oxides and lithic grains and clasts such as quartz-rich metamorphic (e.g. schist, orthogneiss, metagranitoid, mylonite and quartzite), acidic-intermediate volcanic (e.g. andesite, dacite, rhyodacite and rhyolite) and intraformational siliciclastic rocks. No carbonate rock fragments were observed. The poorly to moderately sorted polymict Téseny conglomerate samples are characterized by metamorphic (orthogneiss, quartz-muscovite-albite schist, phyllite, mylonite, metagranitoid, metaquartzite), sedimentary (mudrock, sandstone, chert), and acidic-intermediate volcanic (rhyolite, dacite, trachyandesite, andesite) rock clasts (Hetényi and Ravasz-Baranyai 1976; Varga et al. 2003, 2007).

Previous source-area interpretations identified three main sources of Téseny Sandstone Formation: (1) a recycled Variscan orogenic area, (2) an uplifted plutonic (granite-gneiss) basement, and (3) an old (probably Variscan) magmatic arc (Hetényi and Ravasz-Baranyai 1976; Varga et al. 2001, 2003, 2007; Varga and Szakmány 2004). Unfortunately, there is no evidence for volcanites older than Early Permian in this area; therefore the origin of acidic-intermediate volcanic source components is obscure (Varga et al. 2003). Metamorphic source components might have been derived from local sources in southern Transdanubia, but a detailed description of metamorphic terrains, including whole-rock chemistry, has yet to be carried out (Hetényi and Ravasz-Baranyai 1976; Varga et al. 2007).

Sampling and analytical methods

In the study area, three cored exploration boreholes (Bogádmindszent Bm-1, Diósviszló Dv-3, and Siklósbodony Sb-1) penetrating Téseny clastics were chosen for detailed observations (Figs 2 and 3). The Upper Carboniferous sequence of

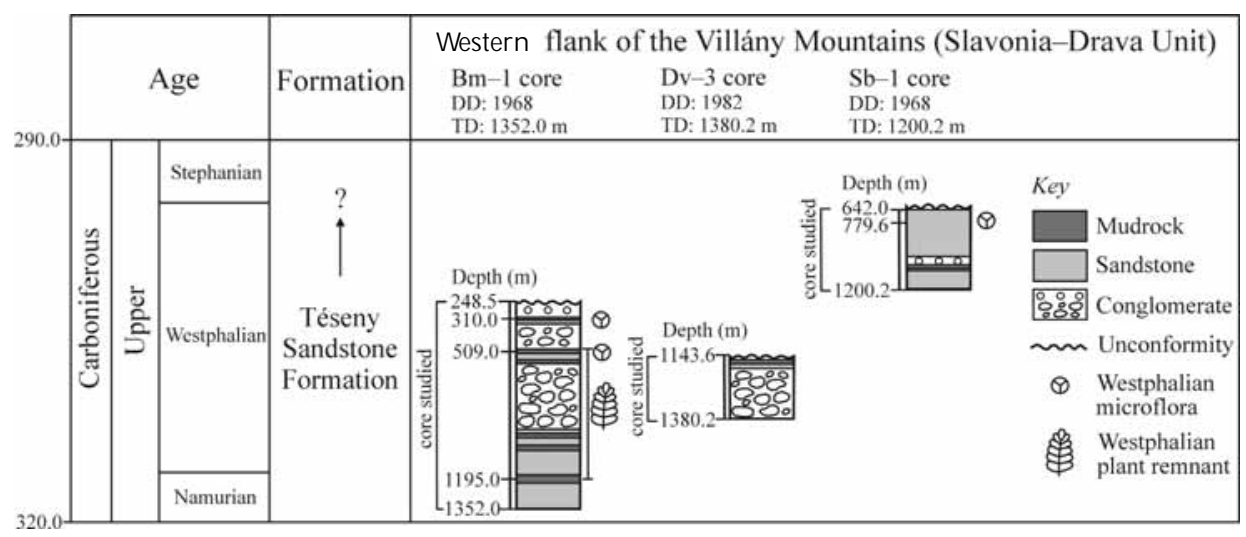

Fig. 3

Schematic lithologic logs of the boreholes, showing the stratigraphic relationships of the cores studied and the position of the investigated section within the hole. Modified after Varga et al. (2007). DD = date of drilling; TD = total depth below the surface 
borehole Bm-1 is composed mainly of coarse and fine-pebble conglomerate, sandstone, siltstone and claystone (Fig. 4). The Téseny rocks of borehole DV-3are composed primarily of coarse-pebble conglomerate alternating with sandstone (Fig. 4). The studied succession from borehole $\mathrm{Sb}-1$ is dominated by fine-pebble conglomerate, sandstone, siltstone, and claystone (Hetényi and Ravasz-Baranyai 1976; Varga et al. 2001, 2003, 2007) (Fig. 4). Greater amounts of K-feldspar and volcanic rock fragments are noted in boreholes Bm-1 and DV-3 (Hetényi and Ravasz-Baranyai 1976; Varga et al. 2001, 2003, 2007; Varga and Szakmány 2004). In borehole Sb-1, plagioclase-rich metamorphic lithic fragments are the main components; K-feldspar and volcanic material appear in low proportions (Hetényi and Ravasz-Baranyai 1976; Varga et al. 2001, 2003, 2004, 2007).

A total of twenty-eight sandstone and sandy siltstone core samples were used for clay mineralogical and geochemical studies. Additionally, fourteen representative samples of pebble-sized orthogneiss and igneous rock clasts extracted from the associated Téseny conglomerate beds from the boreholes mentioned above were collected for the present study (Fig. 4).

The semiquantitative mineral ogical analysis of the clay-sized fraction $(<2 \mu \mathrm{m})$ of the sedimentary rock samples was performed at the Department of Earth and Environmental Sciences of the University of Pannonia (Veszprém, Hungary) by X-ray powder diffraction (XRD), using a Philips PW 1710 diffractometer, Cu-Ka radiation, and diffracted-beam graphite single crystal monochromator. A complete description of the analytical procedures used for XRD analysis is reported in Varga et al. (2007).

Major element abundances of the sedimentary rock samples and extracted clasts were determined at the same institution by X-ray fluorescence (XRF) analysis, using a Philips PW 2404 X-ray spectrometer equipped with a 4-kW Rh anode tube. Duplex, scintillation, and proportional counters were used as detectors, while the analyzing crystals were LiF (200), PE 002-C and PX1. Analytical precision for major elements is $\pm 1.5 \%$ (Hartyáni et al. 2000). Additionally, we have included the geochemical results of six sandstone and sandy siltstone samples collected from borehole Sb-1 to supplement our data set (Varga et al. 2004). Their elemental composition was determined at the Department of Geochemistry, University of Tübingen (Germany), using an X-ray fluorescence spectrometer type Bruker AXS S4 Pioneer with a rhodium X-ray source (Varga et al. 2007).

In this study there was no objective way to distinguish carbonate $\mathrm{CaO}$ from silicate $\mathrm{CaO}$, so total $\mathrm{CaO}$ is used to calculate the $\mathrm{CIA}$ values (Tables 1 and 2 ). This is justified on the basis that none of the samples appeared calcareous, and all samples contained less than $1.00 \mathrm{wt} \% \mathrm{CaO}$, in good agreement with the results of other geochemical studies (Cox et al. 1995; Hassan et al. 1999; Lee 2002).

Fig. $4 \rightarrow$

Generalized lithological columns of the studied Téseny sections, showing the position of the investigated samples (modified after Fülöp 1994) 

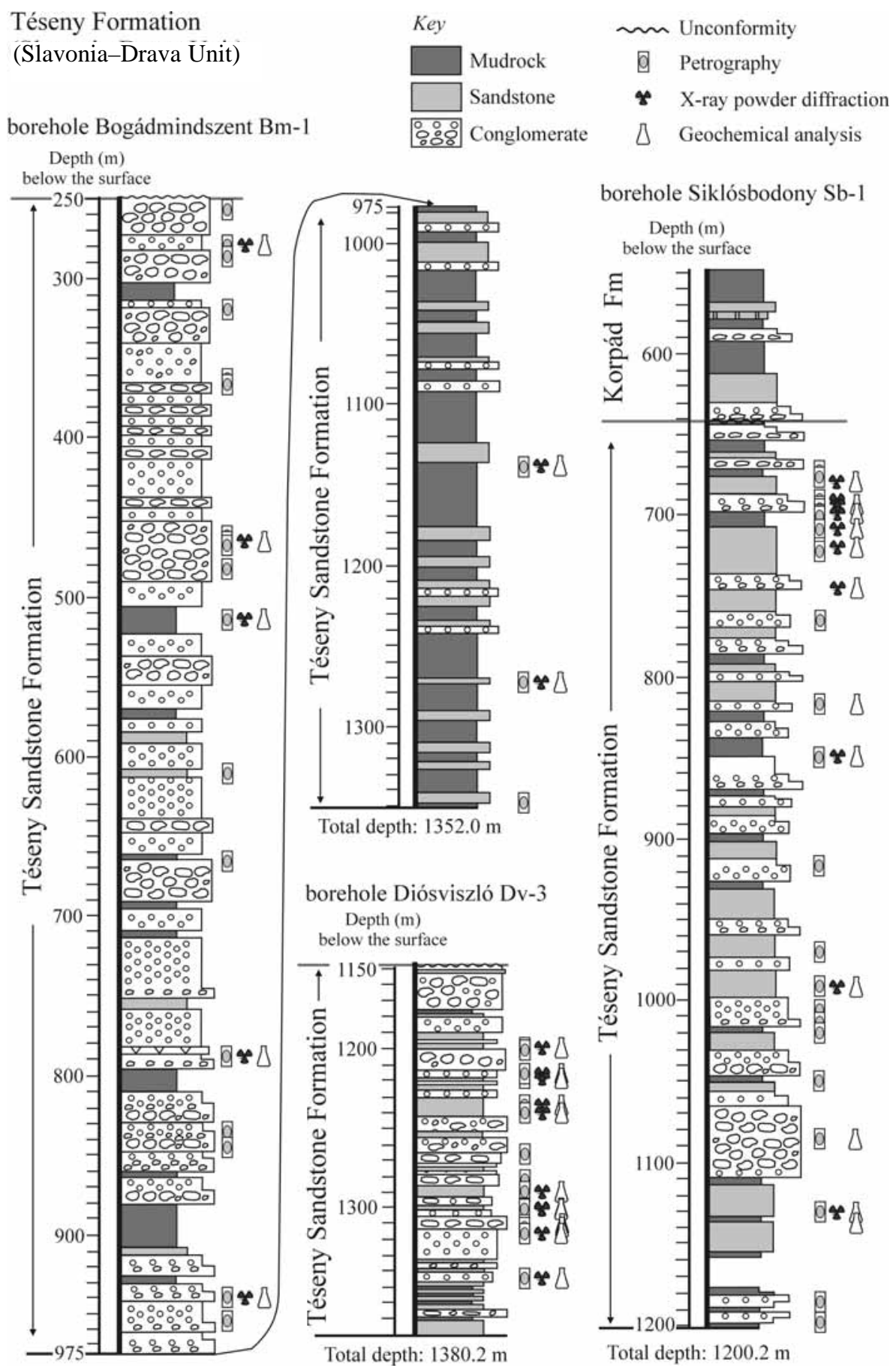

borehole Siklósbodony Sb-1

Depth $(\mathrm{m})$

below the surface

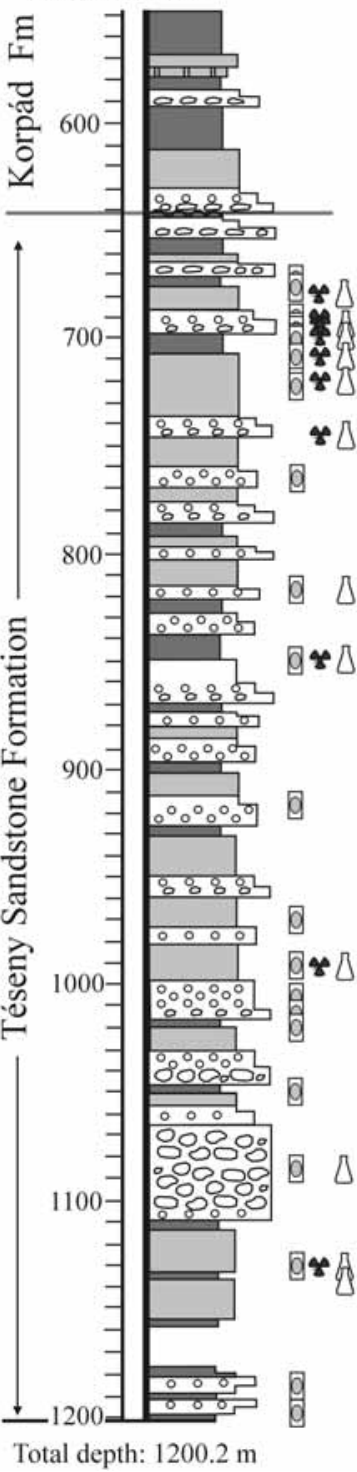

Central European Geology 50, 2007 
10 A. Varga et al.

\section{Results and discussion}

Clay mineralogy

The clay-mineral assemblage of the Téseny siliciclastic rock samples includes illite ( \pm muscovite), kaolinite, and occasionally minor proportions of chlorite with Fe(II)-rich interlayer, rare berthierine and illite/smectite mixed-layer minerals (Table 1). On average, illite is the major phyllosilicate in many of the samples (Fig. 5). Some samples from borehole Dv-3, however, have high kaolinite contents, up to $50 \%$ of the clay-sized fraction.

Table 1

Composition of the Téseny siliciclastic sedimentary rock samples studied from three different boreholes in southern Transdanubia

\begin{tabular}{|c|c|c|c|c|c|c|c|c|c|}
\hline \multirow[t]{2}{*}{ Sample } & ill & chl \pm ber & kao & ill/sme & $\mathrm{Al}_{2} \mathrm{O}_{3}$ & $\mathrm{CaO}$ & $\mathrm{Na}_{2} \mathrm{O}$ & $\mathrm{K}_{2} \mathrm{O}$ & \multirow[t]{2}{*}{ CIA } \\
\hline & \multicolumn{4}{|c|}{$\%$} & \multicolumn{4}{|c|}{$\mathrm{wt} \%$} & \\
\hline Bm-1 278.4-279.8 m & 88 & - & 12 & - & 11.02 & 0.16 & 1.47 & 3.89 & 61 \\
\hline $\mathrm{Bm}-1465.8-466.5 \mathrm{~m}$ & 98 & - & 2 & - & 9.92 & 0.90 & 1.49 & 4.00 & 54 \\
\hline $\mathrm{Bm}-1$ 515.2-516.2 m & 92 & 5 & 8 & - & 20.91 & 0.74 & 0.98 & 5.61 & 70 \\
\hline Bm-1 785.8-786.4 m & 90 & 5 & 5 & - & 19.26 & 0.79 & 1.09 & 5.24 & 68 \\
\hline Bm-1 939.1-940.3 m & 95 & - & 5 & - & 9.42 & 0.10 & 1.18 & 3.19 & 63 \\
\hline Bm-1 1138.2-1138.5 m & 85 & 10 & 5 & - & 12.12 & 0.42 & 1.74 & 2.36 & 66 \\
\hline Bm-1 1273.0-1274.0 m & 90 & 5 & 5 & - & 11.84 & 0.22 & 1.28 & 2.27 & 70 \\
\hline Dv-3 $1199.0 \mathrm{~m}$ & 50 & - & 50 & - & 11.82 & 0.33 & 1.01 & 4.04 & 64 \\
\hline Dv-3 $1218.4 \mathrm{~m}$ & 73 & - & 24 & 3 & 10.50 & 0.33 & 1.52 & 2.93 & 63 \\
\hline Dv-3 $1219.5 \mathrm{~m}$ & 75 & - & 25 & - & 15.05 & 0.29 & 1.62 & 3.64 & 68 \\
\hline Dv-3 $1220.6 \mathrm{~m}$ & ND & ND & ND & ND & 16.72 & 0.20 & 1.42 & 4.25 & 70 \\
\hline Dv-3 $1235.0 \mathrm{~m}$ & 90 & 10 & - & - & 12.30 & 0.14 & 0.15 & 3.30 & 75 \\
\hline Dv-3 $1240.0 \mathrm{~m}$ & 90 & 6 & 4 & - & 12.50 & 0.13 & 0.17 & 3.43 & 75 \\
\hline Dv-3 $1289.0 \mathrm{~m}$ & 95 & - & 5 & - & 10.65 & 0.15 & 0.13 & 3.07 & 74 \\
\hline Dv-3 $1301.2 \mathrm{~m}$ & 80 & - & 18 & 2 & 12.32 & 0.27 & 0.31 & 4.24 & 69 \\
\hline Dv-3 $1301.7 \mathrm{~m}$ & 83 & - & 14 & 3 & 11.41 & 0.24 & 0.70 & 3.94 & 66 \\
\hline Dv-3 $1343.9 \mathrm{~m}$ & 80 & - & 18 & 2 & 13.84 & 0.29 & 1.03 & 4.20 & 67 \\
\hline $\mathrm{Sb}-1673.0-684.0 \mathrm{~m} / \mathrm{b}$ & 80 & 15 & - & 5 & 17.93 & 0.47 & 1.41 & 3.11 & 73 \\
\hline $\mathrm{Sb}-1$ 694.0-697.0 m & 80 & 5 & - & 15 & 19.37 & 0.21 & 1.17 & 3.29 & 77 \\
\hline $\mathrm{Sb}-1697.0-702.0 \mathrm{~m}$ & 95 & 5 & - & - & 21.12 & 0.25 & 1.24 & 4.06 & 75 \\
\hline $\mathrm{Sb}-1697.0-702.0 \mathrm{~m} / \mathrm{b}$ & 95 & 5 & - & - & 19.79 & 0.16 & 1.09 & 3.87 & 76 \\
\hline $\mathrm{Sb}-1697.0-702.0 \mathrm{~m} / \mathrm{e}$ & 95 & 5 & - & - & 17.14 & 0.21 & 0.97 & 3.35 & 75 \\
\hline $\mathrm{Sb}-1708.0-712.0 \mathrm{~m} / \mathrm{d}$ & 70 & 30 & - & - & 22.57 & 0.31 & 1.29 & 4.09 & 76 \\
\hline $\mathrm{Sb}-1739.0-746.0 \mathrm{~m}$ & 90 & - & 10 & - & 21.23 & 0.19 & 1.32 & 4.83 & 73 \\
\hline Sb-1 847.2-850.1 m & 95 & 5 & - & - & 13.01 & 0.14 & 0.37 & 2.57 & 78 \\
\hline $\mathrm{Sb}-1993.2 \mathrm{~m}$ & 90 & 5 & 5 & - & 20.30 & 0.89 & 1.03 & 4.85 & 70 \\
\hline Sb-1 $1130.4-1133.3 \mathrm{~m}$ & 87 & 13 & - & - & 20.37 & 0.30 & 1.58 & 4.21 & 73 \\
\hline Sb-1 $1138.2-1138.5 \mathrm{~m}$ & ND & ND & ND & ND & 10.71 & 0.92 & 2.08 & 1.82 & 60 \\
\hline
\end{tabular}

Legend: ill = illite ( \pm muscovite); chl \pm be $=$ chlorite \pm berthierine; $k a o=$ kaolinite; ill/sme = illite/ smectite mixed-layer; $\mathrm{ClA}=$ Chemical Index of Alteration; ND $=$ no data

The high proportion of illite, together with chlorite, in the clay-mineral assemblage of the core Sb-1 samples confirms the predominance of metamorphic sources for this formation (Varga et al. 2001, 2003). Chlorite with Fe(II)-rich interlayer is present in minor quantity due to its coarser grain-size, suggesting that it is formed by alteration of detrital biotite, and less commonly as authigenic matrix material (Bauluz et al. 1995). Kaolinite, illite and smectite (illite/smectite 
Pal eoweathering conditions of U pper Carboniferous siliciclastic rocks of SW H ungary 11
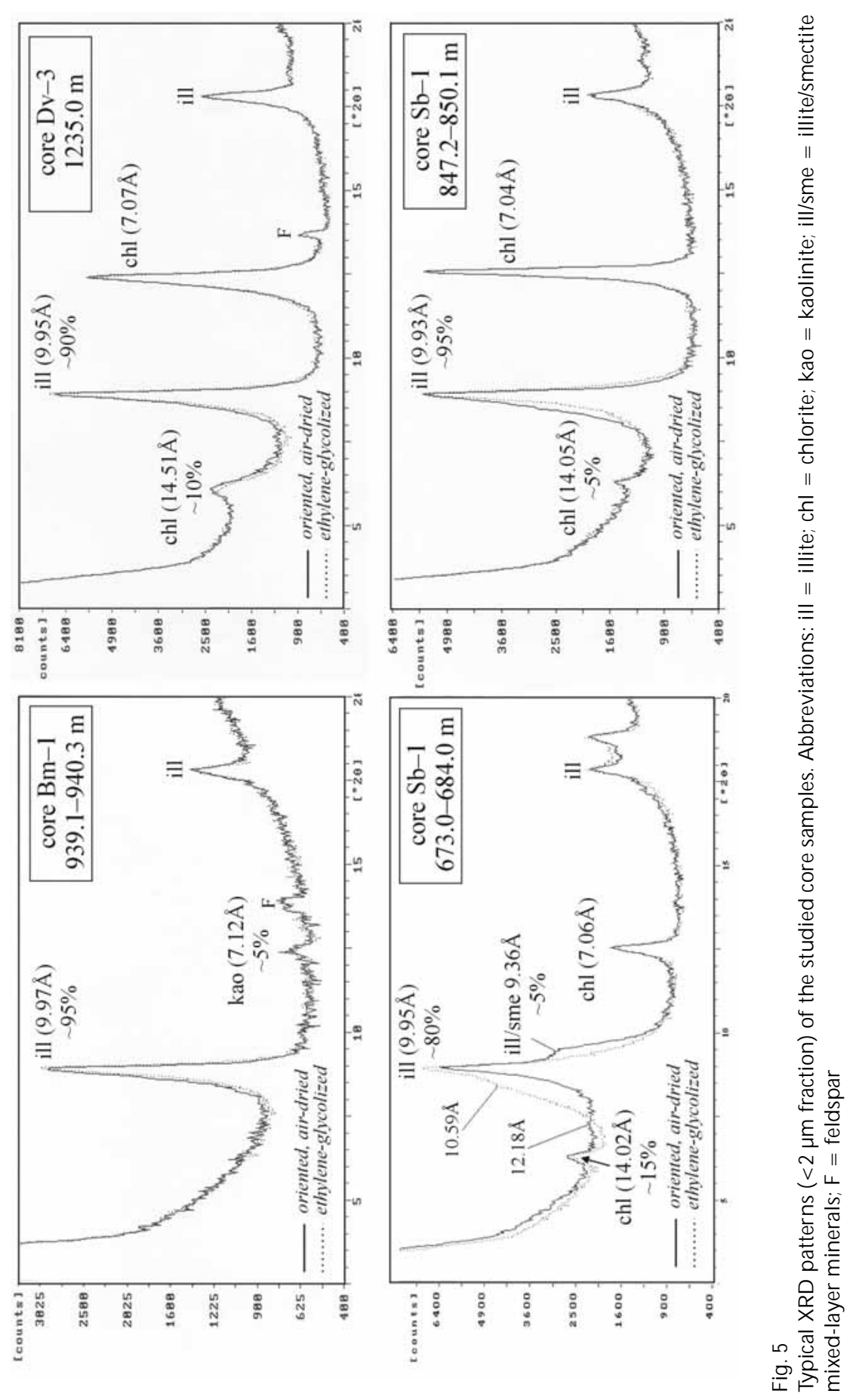

Central European Geology 50, 2007 
mixed-layer) are common clays produced during weathering of primary detrital phases (Nesbitt et al. 1980; Nesbitt and Young 1982, 1984, 1989; Weaver 1989). In comparison with recent profiles developed on granitic rocks, kaolinite should dominate in the alteration products (Nesbitt and Young 1984, 1989) with respect to the petrographic composition of the studied Téseny samples (Hetényi and Ravasz-Baranyai 1976; Varga et al. 2001, 2003, 2007; Varga and Szakmány 2004). However, kaolinite is generally scarce and illite is the most abundant clay mineral (Table 1). These observations suggest that kaolinite has been partially or totally converted to illite. Therefore, the clay mineralogy of the Téseny samples probably reflects the effects of K-metasomatism, which is favored around the periphery of subsiding continental sedimentary basins where dilute continental ground waters display low $\mathrm{Na}$ /K values (Fedo et al. 1995, 1996). This scenario is supported by the presence of abundant illite/sericite, both as matrix material between grains, and as alteration of weathered feldspar grains (Varga et al. 2007).

$D$ egree of subaerial weathering

$\mathrm{CIA}$ values for the clasts studied from the Téseny conglomerate range from 49 to 62 (Table 2), with an average of 56, a value typical for weakly weathered protoliths. The weathered state of the extracted clast samples, corresponding to the fluvial facies, clearly reflects that the parent rocks were exposed to subaerial weathering agents.

$\mathrm{CIA}$ values for sandstone and sandy siltstone samples from borehole $\mathrm{Bm}-1$ range from 54 to 70 (average: 65), from 63 to 75 (average: 69) for samples from borehole Dv-3, and from 60 to 78 (average: 73 ) for samples from borehole Sb-1 (Table 1). These data may indicate a weak to moderate degree of chemical weathering in the source area. Such an interpretation is consistent with the conclusions of a previous study on sandstone of the Téseny Formation (Varga et al. 2002). On the other hand, the results of the clay mineralogical study discussed above indicate that some potassium metasomatism occurred in these samples, lowering the CIA values (Varga et al. 2007). It is necessary to evaluate the effects of this metasomatic event before interpreting weathering conditions (Fedo et al. 1995).

\section{A nalysis of weathering trends}

Compositional trends of the potential parent rocks (unweathered protoliths) cannot be drawn in the $\mathrm{A}-\mathrm{CN}-\mathrm{K}$ diagram because the requisite chemical data are not yet available; nevertheless, a prediction can be made of weathering trends, based on the elemental composition of extracted orthogneiss and igneous rock clasts (Fig. 6). Figure 6 also shows the bulk compositions of average granodiorite (tonalite-trondhjemite-granodiorite), granite, andesite, and felsic volcanite from Condie (1993). The data points of the clast samples collected from the Téseny conglomerate define two different trends (Fig. 6). Both trends are subparallel to 
Table 2

Composition of the gneiss and igneous rock clast samples

\begin{tabular}{|c|c|c|c|c|c|c|c|}
\hline \multirow[t]{2}{*}{ Sample code } & Lithology & $\mathrm{Al}_{2} \mathrm{O}_{3}$ & $\mathrm{CaO}$ & $\mathrm{Na}_{2} \mathrm{O}$ & $\mathrm{K}_{2} \mathrm{O}$ & \multirow[t]{2}{*}{ CIA } & \multirow[t]{2}{*}{ PWT } \\
\hline & \multicolumn{5}{|c|}{$\mathrm{wt}^{\mathrm{N}} \%$} & & \\
\hline $\mathrm{Bm}-1 / \mathrm{V} 1$ & Dacite & 13.80 & 0.30 & 6.20 & 3.30 & 49 & trend-a \\
\hline Dv-3/GR3 & Aplite & 11.50 & 0.55 & 2.71 & 4.65 & 52 & trend-b \\
\hline Dv-3/GR5 & Quartz diorite & 13.60 & 0.42 & 3.06 & 2.28 & 62 & trend-a \\
\hline Dv-3/V3 & Andesite & 14.70 & 0.69 & 1.80 & 5.10 & 60 & trend-b \\
\hline Dv-3/V5 & Andesite & 15.40 & 0.46 & 2.20 & 4.80 & 61 & trend- $b$ \\
\hline Dv-3/GR2 & Rhyodacite & 14.80 & 0.59 & 2.22 & 5.41 & 58 & trend-b \\
\hline Dv-3/V1 & Rhyodacite & 11.10 & 0.46 & 6.30 & 0.40 & 49 & - \\
\hline $\mathrm{Dv}-3 / \mathrm{V} 2$ & Rhyodacite & 14.80 & 0.45 & 3.80 & 2.90 & 59 & trend-a \\
\hline Dv-3/V4 & Rhyolite & 13.70 & 0.59 & 3.10 & 5.00 & 54 & trend-b \\
\hline Dv-3/GR4 & Rhyolite & 13.10 & 0.33 & 2.98 & 5.15 & 54 & trend-b \\
\hline $\mathrm{Sb}-1 / \mathrm{G} 1$ & Orthogneiss & 14.70 & 0.38 & 3.90 & 2.20 & 61 & trend-a \\
\hline $\mathrm{Sb}-1 / \mathrm{K} 1$ & Orthogneiss & 13.90 & 0.54 & 4.47 & 2.08 & 57 & trend-a \\
\hline $\mathrm{Sb}-1 / \mathrm{GR} 1$ & Orthogneiss & 12.50 & 0.48 & 3.58 & 1.86 & 59 & trend-a \\
\hline $\mathrm{Sb}-1 / \mathrm{V} 1$ & Andesite & 14.30 & 0.75 & 5.30 & 1.90 & 54 & trend-a \\
\hline
\end{tabular}

Legend: $\mathrm{CIA}=$ Chemical Index of Alteration; $\mathrm{PWT}=$ predicted weathering trend

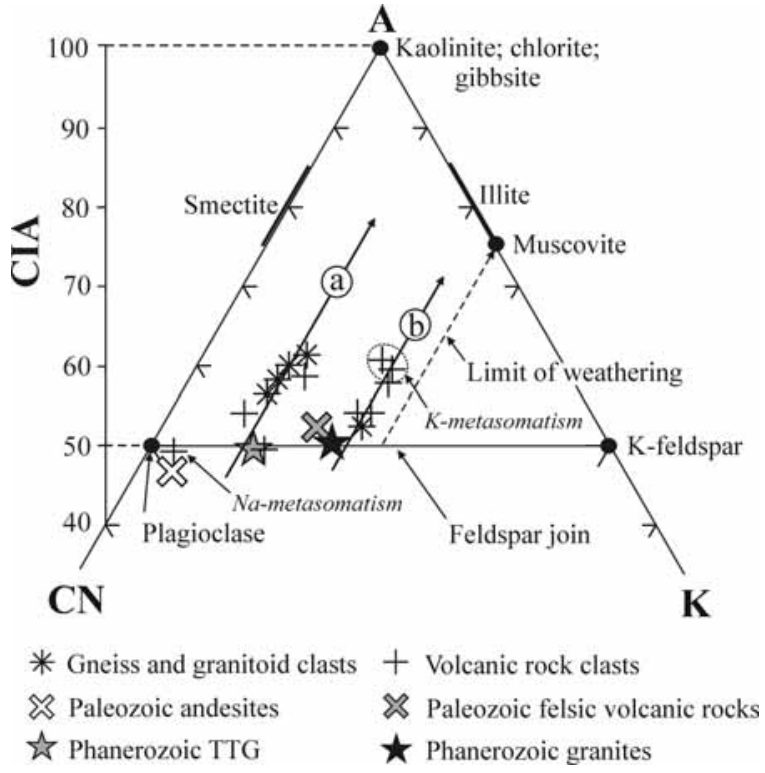

Fig. 6

Ternary A-CN-K plot (Nesbitt and Young 1984, 1989) for the gneiss and igneous rock clast samples collected from the Téseny conglomerate (molar proportions). Average chemical data for igneous rocks (TTG $=$ tonalite-trondhjemite-granodiorite) represent typical unweathered protoliths (Condie 1993). The samples plot subparallel to the A-CN join, suggestive of ideal weathering of (a) a granodioritic source, and (b) a more felsic source. Note that only the top $60 \%$ of the triangle is shown

the $\mathrm{A}-\mathrm{CN}$ boundary, indicating that $\mathrm{Ca}$ and $\mathrm{Na}$ are removed in preference to $\mathrm{K}$ (Nesbitt and Young 1984, 1989). The degree of weathering for the studied clasts (vertical dimension $=\mathrm{CIA}$ ) is quite variable, producing scatter along the trends. This pattern is typical of non-steady state weathering conditions, where active tectonism permits erosion of all zones within weathering profiles developed on source rocks (Nesbitt et al. 1997). A high erosion rate is also indicated by the abundance of coarse clastics in the sequences from boreholes Bm-1 and Dv-3 
(Hetényi and Ravasz-Baranyai 1976; Varga et al. 2003, 2007; Varga and Szakmány 2004).

According to this interpretation, the two different weathering trends in the Téseny Formation may indicate the mixing of sediments from two different source rocks. Trend-a (including orthogneiss, quartz diorite and andesite samples) is typical of granodioritic weathering profiles from a starting point close to the average chemical composition of Phanerozoic granodiorite from Condie (1993). Trend-b (including aplite, rhyodacite and rhyolite samples) is similar to the initial weathering trends observed over granitic rocks from a starting point close to the composition of Phanerozoic granites from Condie (1993) toward the muscovite-kaolinite join, with a small displacement toward the $K$ apex. This suggests that these Téseny clast samples were derived from a progressively more felsic source area, following a trend from a slightly more K-feldspar-rich fresh rock composition than that of average granites. Another possibility is that the variation indicates that some potassium metasomatism occurred in these samples. Conversion of secondary aluminous clay minerals such as kaolinite to illite by $\mathrm{K}$ addition results in a lower $\mathrm{CIA}$ value than for the premetasomatized rock (Fedo et al. 1995).

It is important to note that one rhyodacite sample (sample DV-3/V1; corresponding to the rhyolite field in the $\mathrm{SiO}_{2}$ (wt\%) vs. $\mathrm{Na}_{2} \mathrm{O}+\mathrm{K}_{2} \mathrm{O}(w t \%)$ chemical classification diagram; Szakmány 2001, unpublished data) plots close to the plagioclase position (Fig. 6). This sample contains $6.30 \mathrm{wt} \% \mathrm{Na}_{2} \mathrm{O}$ whereas $\mathrm{CaO}$ is $0.46 \mathrm{wt} \%$ and $\mathrm{K}_{2} \mathrm{O}$ is $0.40 \mathrm{wt} \%$ (Table 2). $\mathrm{Na}_{2} \mathrm{O}$ is $\sim 3.5 \mathrm{wt} \%$ in the unweathered Paleozoic felsic volcanic rocks (Condie 1993). This suggests that $\mathrm{Na}$ has been added to the parent rock as albite ( $\mathrm{Na-metasomatism).}$

On the other hand, the andesite samples studied from borehole Dv-3 plot away from the expected weathering trend of granodioritic (andesitic) rocks, following the granitic trend-b. These samples contain 5.10 and $4.80 \mathrm{wt} \% \mathrm{~K}_{2} \mathrm{O}$, respectively (Table 2 ), whereas $\mathrm{K}_{2} \mathrm{O}$ is $\sim 1.3 \mathrm{wt} \%$ in the fresh Paleozoic andesites (Condie 1993). This characteristic is most readily interpreted by assuming an ancient rock that was subjected to K-metasomatism, partially converting kaolinite to illite and slightly lowering CIA (Fedo et al. 1995).

As discussed above, some source materials of the Téseny siliciclastic sedimentary rocks have been affected significantly by diagenetic reactions, including $\mathrm{Na}$ - or K-metasomatism. We suggest, therefore, that the clast samples corresponding to the inferred weathering trend-b suffered K-metasomatism, reflecting either peculiar soil-forming processes in the Late Carboniferous, or post-depositional alteration.

A-CN-K diagram for Téseny sedimentary rocks

On the A-CN-K diagram (Fig. 7) the sandstone samples from boreholes Bm-1 and Dv-3 plot away from the inferred weathering trend-a of granodioritic rocks. 
The majority of these samples plot along Trend-b, in a position consistent with derivation from moderately to highly weathered granite (Nesbitt and Young 1984, 1989; Fedo et al. 1996). Additionally, some samples from borehole Dv-3 are slightly enriched in $\mathrm{K}_{2} \mathrm{O}$ relative to the "limit of weathering" line. Assuming potassium metasomatism occurred in the Téseny siliciclastic sedimentary rocks (as indicated by the abundance of illitic material in the clay fraction), and if the interpretation of a $\mathrm{K}$ enrichment in clasts belonging to the weathering trend- $\mathrm{b}$ is correct, the original $\mathrm{CIA}$ values of these sandstone samples prior to $\mathrm{K}$ enrichment cannot be determined in the $\mathrm{A}-\mathrm{CN}-\mathrm{K}$ space.

On the other hand, the siliciclastic sedimentary rocks from borehole Sb-1 were derived from a simple source area dominated by plagioclase-rich crystalline rocks, corresponding to the granodioritic trend, as supported by previous

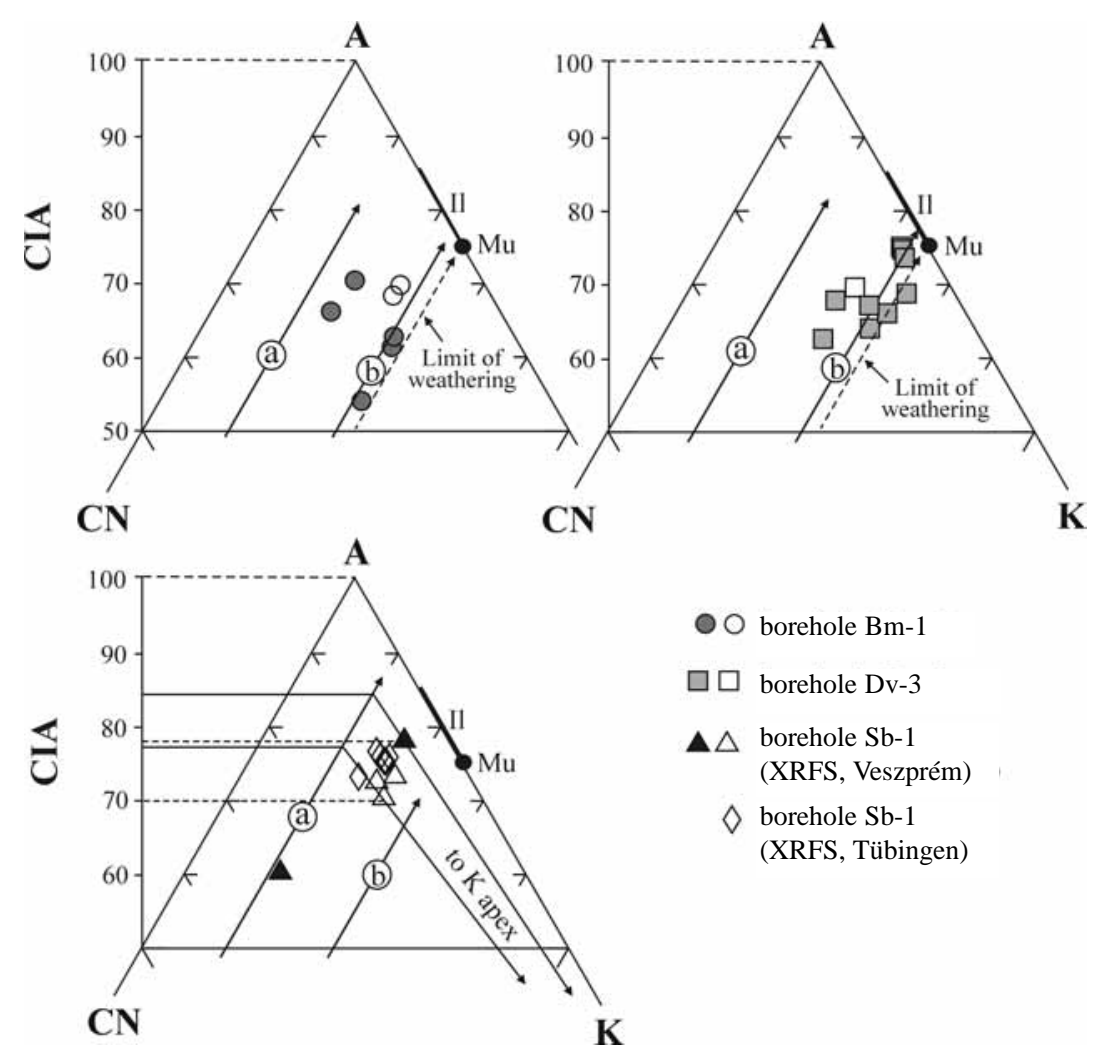

Fig. 7

Ternary A-CN-K plot (Nesbitt and Young 1984, 1989) for the Téseny siliciclastic sedimentary rock samples (molar proportions). The open symbols represent the compositions of sandy siltstone to finegrained sandstone, and solid symbols represent medium to very coarse-grained sandstone. Mineral abbreviations: $\mathrm{II}=$ illite; $\mathrm{Mu}=$ muscovite. Note that only the top $50 \%$ of the triangle is shown 
petrologic data (Hetényi and Ravasz-Baranyai 1976; Varga et al. 2001, 2003, 2004, 2007). The major element data of these samples (except for the sample studied from the base of the sequence) plot in a very limited region, diagnostic of steadystate conditions, where material removal rate matches the production of mineralogically uniform weathering products generated in the upper zone of soil development (Nesbitt et al. 1997). All samples plot on the $\mathrm{K}_{2} \mathrm{O}$-rich side of the inferred weathering trend-a (Fig. 7), indicating a substantial enrichment in $\mathrm{K}_{2} \mathrm{O}$ when compared with trends for recent granodioritic profiles (Nesbitt and Young 1984, 1989). Because this type of $\mathrm{K}$ enrichment involves addition of $\mathrm{K}_{2} \mathrm{O}$ to aluminous clays, it follows a path toward the $\mathrm{K}_{2} \mathrm{O}$ apex of the triangle (Fedo et al. 1995). A line from the K apex through the sample point studied from borehole Sb1 intersects the predicted weathering trend-a at a point representing its premetasomatized composition (Fig. 7). Two analyses of the sandstone samples from borehole Sb-1 illustrate the technique to correct for K-metasomatism. These samples have intermediate $\mathrm{CIA}$ values (70 and 78 , respectively), whereas the premetasomatic $\mathrm{ClA}$ values are 77 and 84 . A quantitative estimate of $\mathrm{K}$ enrichment is determined by the difference between the premetasomatized $\mathrm{CIA}$ and the current value (Fedo et al. 1995, 1996). Téseny sandstones thus have a minimum range of $\mathrm{K}_{2} \mathrm{O}$ addition of $6-7 \%$ in $\mathrm{A}-\mathrm{CN}-\mathrm{K}$ space.

Although precise premetasomatic CIA values cannot be ascertained, this result suggests that the Téseny siliciclastic sedimentary rocks developed under intermediate to extreme ( $\mathrm{CIA}>80)$ chemical weathering conditions. Therefore, in general, the $\mathrm{CIA}$ values corrected for $\mathrm{K}$-metasomatism indicate that their primitive source areas underwent a more intense chemical weathering.

\section{Conclusions}

Clay mineralogical and major element analyses of the Upper Carboniferous siliciclastic sedimentary rocks in southern Transdanubia (Téseny Sandstone Formation, Hungary) yield several conclusions with regard to source-area weathering conditions and post-depositional modifications:

1. The clay mineralogy of the Téseny sedimentary rocks reflects the effect of variable degrees of $\mathrm{K}$-metasomatism (illitization), which is common in continental settings.

2. Orthogneiss and igneous rock clasts extracted from the Téseny conglomerate show two different trends; one shows an ideal weathering trend observed over granodioritic rocks, and the other follows a trend from a fresh rock composition that is slightly more K-feldspar-rich than average granite. Additionally, some source materials have been affected by K- or $\mathrm{Na}$-metasomatism.

3. The sedimentary rock samples were derived from source terrains where intermediate to extreme chemical weathering produced intermediate to high $\mathrm{ClA}$ indices which were subsequently decreased by K-metasomatism to the present values (54-78). 
4. When considered in A-CN-K compositional space, the distribution of the samples from borehole Sb-1 lies far off of the granodioritic weathering trend-a. Their position indicates that the Téseny region experienced a major $\mathrm{K}$ metasomatic event that added $6-7 \% \mathrm{~K}_{2} \mathrm{O}$ (in A-CN-K space) to the sandstones via conversion of kaolinite to illite. The timing of this event is uncertain.

\section{Acknowledgements}

The Mecsek Ore Environment Company (Pécs, Hungary) made the core samples from boreholes Bm-1, Dv-3, and Sb-1 available for study. The authors are grateful to T. Horváth, S. Józsa, L. Merényi, Z. Máthé, F. Pintér, V. Szilágyi and H. Taubald for their constructive help in field and laboratory work. Funding for this work came from several sources, including the Hungarian Scientific Research Fund (OTKA) projects T 022938, and T 034924 to György Szakmány and T 26423, and T 043574 to Zsuzsanna Hartyáni, and the International Association of Sedimentologists grant 2003 to Andrea Varga. This study also forms part of Andrea Varga's Ph.D. research at Eötvös University (Budapest, Hungary).

\section{References}

Bauluz, B., M.J. Mayayo Burillo, C. Fernandez-Nieto, J.M. Gonzalez Lopez 1995: Mineralogy and geochemistry of Devonian detrital rocks from the Iberian Range (Spain). - Clay Minerals, 30 , pp. 381-394.

Condie, K.C. 1993: Chemical composition and evolution of the upper continental crust: Contrasting results from surface samples and shales. - Chemical Geology, 104, pp. 1-37.

Cox, R., D.R. Lowe, R.L. Cullers 1995: The influence of sediment recycling and basement composition on evolution of mudrock chemistry in the southwestern United States. Geochimica et Cosmochimica Acta, 59/14, pp. 2919-2940.

Fedo, C.M., H.W. N esbitt, G.M. Young 1995: Unraveling the effects of potassium metasomatism in sedimentary rocks and paleosols, with implications for paleoweathering conditions and provenance. - Geology, 23, pp. 921-924.

Fedo, C.M., K.A. Eriksson, E.J. Krogstad 1996: Geochemistry of shales from the Archean ( 3.0 Ga) Buhwa Greenstone Belt, Zimbabve: Implications for provenance and source-area weathering. Geochimica et Cosmochimica Acta, 60, pp. 1751-1763.

Fülöp, J. 1994: Magyarország geológiája. Paleozoikum II (Geology of Hungary. Paleozoic, II). Akadémiai Kiadó, Budapest, 447 p. (In Hungarian.)

Gaillardet, J., B. Dupré, C.J. Allegre 1999: Geochemistry of large river suspended sediments: Silicate weathering or recycling tracer. - Geochimica et Cosmochimica Acta, 63/23-24, pp. 4037-4051.

Haas, J., G. Hámor, L. Korpás 1999: Geological setting and tectonic evolution of Hungary. Geologica Hungarica Ser. Geol., 24, pp. 179-196.

Hartyáni, Zs., I. Pécsi, S. Szabó, J. Szauer, L. Merényi, V. Szilágyi 2000: Mineralogical and chemical investigation of soil formed on basaltic bentonite at Egyházaskeszõ, Transdanubia, Hungary. Acta Geol. Hung., 43/4, pp. 431-446.

Hassan, S., I. Hiroaki, B.P. Roser, K. Dozen, T. Naka 1999: Geochemistry of Permian-Triassic shales in the Salt Range, Pakistan: Implications for provenance and tectonism at the Gondwana margin. - Chemical Geology, 158, pp. 293-314.

Hetényi, R., L. Ravasz-Baranyai 1976: A baranyai antracittelepes felsõkarbon összlet a Siklósbodony 1. és a Bogádmindszent 1. sz. fúrás tükrében (The anthracitiferous Upper Carboniferous 
18 A. Varga et al.

sequence of Baranya, South Hungary, in the light of boreholes Siklósbodony- 1 and Bogádmindszent-1). - MÁFI Évi Jelentése az 1973. évrõl, pp. 323-361. (In Hungarian, with English abstract.)

Jámbor, Á. 1969: Karbon képzõdmények a Mecsek és a Villányi-hegység közötti területen (Carboniferous deposits in the area between the Mecsek and Villány Mountains). - MÁFI Évi Jelentése az 1967. évrõl, pp. 215-221. (In Hungarian, with English abstract.)

Lee, Y.I. 2002: Provenance derived from the geochemistry of late Paleozoic-early Mesozoic mudrocks of the Pyeongan Supergroup, Korea. - Sedimentary Geology, 149, pp. 219-235.

Nesbitt, H.W., G.M. Young 1982: Early Proterozoic climates and plate motions inferred from major element chemistry of lutites. - Nature, 299, pp. 715-717.

Nesbitt, H.W., G.M. Young 1984: Prediction of some weathering trends of plutonic and volcanic rocks based on thermodynamic and kinetic considerations. - Geochimica et Cosmochimica Acta, 48, pp. 1523-1534.

Nesbitt, H.W., G.M. Young 1989: Formation and diagenesis of weathering profiles. - Journal of Geology, 97, pp. 129-147.

Nesbitt, H.W., G. Markovics, R.C. Price 1980: Chemical processes affecting alkalines and alkaline earths during continental weathering. - Geochimica et Cosmochimica Acta, 44, pp. 1659-1666.

Nesbitt, H.W., C.M. Fedo, G.M. Young 1997: Quartz and feldspar stability, steady and nonsteadystate weathering, and petrogenesis of siliciclastic sands and muds. - Journal of Geology, 105, pp. 173-191.

Szederkényi, T. 2001: Tisza Mega-unit. - In: Haas, J. (Ed.): Geology of Hungary. Eötvös University Press, Budapest, pp. 148-169.

Varga, A.R., Gy. Szakmány 2004: Geochemistry and provenance of the Upper Carboniferous sandstones from borehole Diósviszló-3 (Téseny Sandstone Formation, SW Hungary). - Acta Mineralogica-Petrographica, Szeged, 45/2, pp. 7-14.

Varga, A., Gy. Szakmány, S. Józsa, Z. Máthé 2001: A nyugat-mecseki alsó-miocén konglomerátum karbon homokkõ kavicsainak és a Tésenyi Homokkõ Formáció képzõdményeinek petrográfiai és geokémiai összehasonlítása (Petrographic and geochemical comparison between the Carboniferous sandstone pebbles of the Lower Miocene conglomerate from western Mecsek Mts. and Téseny Sandstone Formation). - Földtani Közlöny, 131, pp. 11-36. (In Hungarian, with English abstract.)

Varga, A., B. Raucsik, Gy. Szakmány, Zs. Hartyáni, V. Szilágyi, T. Horváth 2002: Mállási indexek összehasonlítása: a kémiai mállás hatása törmelékes kõzetek ásványos összetételére (Comparison of weathering indices: the effects of chemical weathering of mineralogical composition of siliciclastic rocks). - Magyar Kémiai Folyóirat, 108/9, pp. 387-396. (In Hungarian, with English abstract.)

Varga, A.R., Gy. Szakmány, S. Józsa, Z. Máthé 2003: Petrology and geochemistry of Upper Carboniferous siliciclastic rocks (Téseny Sandstone Formation) from the Slavonian-Drava Unit (Tisza Megaunit, S Hungary) - summarized results. - Acta Geologica Hungarica, 46/1, pp. 95-113.

Varga, A.R., B. Raucsik, Gy. Szakmány 2004: A Siklósbodony Sb-1 mélyfúrás feltételezett karbon-perm határképzõdményeinek ásványtani, kõzettani és geokémiai jellemzõi (Mineralogical, petrographic and geochemical characteristics of siliciclastic rocks from the supposed Carboniferous-Permian boundary in borehole Siklósbodony Sb-1, southwestern Hungary). - Földtani Közlöny, 134/3, pp. 321-343. (In Hungarian, with English abstract.)

Varga, A., Gy. Szakmány, T. Árgyelán, S. Józsa, B. Raucsik, Z. Máthé 2007: Complex examination of the Upper Paleozoic siliciclastic rocks from southern Transdanubia, SW Hungary Mineralogical, petrographic, and geochemical study. - In: Arribas, J., S. Critelli, M.J. Johnsson (Eds): Sedimentary Provenance and Petrogenesis: Perspectives from Petrography and Geochemistry. Geological Society of America Special Paper, 420, pp. 221-240.

Weaver, C.E. 1989: Clays, Muds, and Shales. - Elsevier, Amsterdam, 819 p. 